\title{
ANALYSIS OF COVID-19 COVERAGE IN BANGLADESH NEWS MEDIA USING TOPIC MODELLING
}

\author{
Dipok Chandra Das, Dipanita Saha, Tahrim Kabir, Prosanto Deb, Joy Bhowmik \\ Institute of Information Technology, Noakhali Science and Technology University \\ Noakhali-3814, Bangladesh
}

\begin{abstract}
Coronavirus Disease-2019, commonly known as COVID-19, originated from China has spread all over the globe including Bangladesh. News media of this country have been reporting both local and global news about the spread of COVID-19 since January 2020. Among news media, newspaper plays an important role to establish communication among health authorities, local government and people in risk issues like COVID-19. In this study, we have collected Bangladesh newspaper articles dated from 01 January 2020 to 30 April 2020 and have analyzed their coverage of COVID-19 applying topicmodelling technique. The median value of presence rate of daily COVID-19 related articles is increased from $4.2 \%$ to 67.5\% after confirmed cases in Bangladesh. Newspaper has frequently reported about the spread of COVID-19 (number of tests, cases, deaths and recoveries) and healthcare system of different countries. Before local confirmed cases, the focuses of reporting of newspaper articles are: characteristics of COVID-19 (symptoms, diagnosis, infection, prevention) and preparedness of health authorities of Bangladesh. But after local confirmed cases, the articles have focused on authorities' response, protective measures, treatments of COVID-19 and its impact on people from all sectors of this country especially garment, agriculture, education, etc.
\end{abstract}

Keywords - news media; COVID-19; Bangladesh; newspaper; topic modelling

\section{INTRODUCTION}

The world is going through public health crisis namely COVID-19 pandemic. Cases of pneumonia caused by unknown reason were emerging in the hospitals of China since December 2019 (WHO, 2020, January 21). World Health Organization (WHO) has informed through Twitter about outbreak of new virus on first week of January, 2020 (WHO, 2020, "Timeline of WHO's response to COVID-19"). Since then, news media from all over the world have been covering reports on outbreak of new virus latter named as COVID-19. News media play as a bridge between people and different kinds of organizations like government, health organizations, etc. to communicate and share information. News media help to shape public opinion on happenings, events around the world and to construct risk perception in issues like global climate change, war, disease outbreak. Alongside traditional news media (like TV, Radio, Newspapers, etc.), social media (like Facebook, Twitter, etc.) have emerged as important platforms for sharing public opinion and perception about different issues. Traditional news media discuss about issues with facts and scientific information but discussions on social media are often polarized, unorganized and incomplete. After the spread of COVID-19 in China and Europe countries i.e. Italy, Bangladesh has reported its first confirmed case on March 08 when there are globally about 109577 confirmed cases and 3809 deaths (WHO, 2020, March 09). As of April 30, 'Institute of Epidemiological, Disease Control and Research' (IEDCR) has confirmed 7667 cases and 168 deaths in Bangladesh (IEDCR, 2020). Local news media of Bangladesh have been reporting news about the spread of COVID-19 since its outbreak at Wuhan in China. News media are important ways to disseminate information about new risk issues like COVID-19 towards people to raise public awareness and to construct risk perception. Newspaper is a more reliable and cost-effective source of primary and recent information for common people among the traditional news media in Bangladesh (Akanda, 2013; Genilo, 2016). The people can know about local authorities' policies and preparedness for risk issues through newspaper. Conversely, the authorities can know about public risk perception.

The content analysis of news media coverage on risk issues is a field of study. Recently, there are some related studies on COVID-19. Liu et al. (2020) have analyzed COVID-19 coverage of news media in China to understand the role of health communications between health stakeholders and people. Mahima et al. (2020) have conducted content analysis on vernacular newspapers of India to extract the focus of reporting on COVID-19. Islam et al. (2020) have studied the perception of people of Bangladesh towards governments' response against COVID-19 by reviewing news from different sources. Bhuiyan et al. (2020) have investigated several suicide cases reported in newspapers of Bangladesh and have found that COVID-19 related misinformation and economic impact resulted from lockdown are the main causes. Popular social media, Twitter's tweets have been analyzed to extract public perception towards COVID-19 (Abd-Alrazaq, 2020; Zhao, 2020). There are similar news media related studies on disease outbreak and risk issues: swine flu (H1N1 flu) outbreak in United Kingdom (Hilton, 2011), Middle East Respiratory Syndrome Coronavirus (MERS-CoV) outbreak in South Korea (Choi, 2017), Ebola virus disease (EVD) outbreak (Kim, 2016), climate change issues in Bangladesh (Miah, 2011), etc.

In this study, we have collected popular English daily newspaper, The Daily Star of Bangladesh, articles between January 2020 and April 2020. After text pre-processing on articles, we have applied topic-modelling (Latent Dirichlet Allocation) technique to extract focus of reporting on COVID- 
International Journal of Engineering Applied Sciences and Technology, 2020

Vol. 5, Issue 7, ISSN No. 2455-2143, Pages 27-34

Published Online November 2020 in IJEAST (http://www.ijeast.com)

19. To our knowledge this is the first study on investigation of

COVID-19 outbreak coverage in Bangladesh news media

Table 1. Sections of Newspaper and COVID-19 Presence

\begin{tabular}{|l|l|l|c|c|}
\hline \multicolumn{1}{|c|}{ Section Name } & \multicolumn{1}{|c|}{ Description } & $\begin{array}{l}\text { First COVID-19 } \\
\text { articles }\end{array}$ & \multicolumn{2}{c|}{ Total articles (COVID-19 articles) } \\
\cline { 3 - 5 } & & \multicolumn{1}{|c|}{ Phase-I } & Phase-II \\
\hline FRONT PAGE & $\begin{array}{l}\text { First page of the newspaper. It is the most significant } \\
\text { section of a newspaper. Top news of the day appears } \\
\text { here. }\end{array}$ & $2020-01-22$ & $338(44)$ & $398(314)$ \\
\hline NEWS & Articles on news, events, etc. & $2020-01-21$ & $241(25)$ & $181(114)$ \\
\hline CITY & $\begin{array}{l}\text { Articles on news of cities like Dhaka, Chittagong, } \\
\text { Sylhet, etc. }\end{array}$ & $2020-01-29$ & $857(12)$ & $806(330)$ \\
\hline INTERNATIONAL & Articles about other countries all over the globe. & $2020-01-08$ & $656(66)$ & $738(502)$ \\
\hline EDITORIAL & $\begin{array}{l}\text { Articles on different issues discussed by editorial } \\
\text { board members. }\end{array}$ & $2020-01-26$ & $202(8)$ & $231(153)$ \\
\hline OPINION & $\begin{array}{l}\text { Articles on opinions by authors outside of } \\
\text { newspaper's editorial board. }\end{array}$ & $2020-02-01$ & $106(4)$ & $115(61)$ \\
\hline $\begin{array}{l}\text { LETTERS TO THE } \\
\text { EDITOR }\end{array}$ & $\begin{array}{l}\text { Letters published as articles sent from the reader } \\
\text { COUNTRY 2020-02-11 }\end{array}$ & $27(1)$ & $35(22)$ \\
\hline BACK PAGE & $\begin{array}{l}\text { Articles on news of rural areas are published in this } \\
\text { section. }\end{array}$ & $2020-02-01$ & $272(1)$ & $166(33)$ \\
\hline
\end{tabular}

\section{METHODOLOGY}

\section{A. Data Collection \& Data Cleaning}

For our study, we have selected a representative newspaper of Bangladesh namely The Daily Star, the largest circulated English daily newspaper in this country (Genilo, 2016). The electronic form of daily edition is distributed in their official website (The Daily Star, 2020). We have downloaded the editions in portable file format (.pdf) between January 12020 and April 30 2020. We have extracted newspaper articles (in short, articles) from those editions and stored them in comma separated (.csv) files. We have defined each article having five attributes: date-date of the article, headline-short description of the article covering whole topic, author-writer of the article, body-the textual content of the article, figure captions-the associated textual captions of figures like chart, image, etc. of the article and section-the name of section where that article is appeared. The articles are published in diverse sections. Each section covers its section centered news (for example INTERNATIONAL section publishes news of other countries). The selected sections of the newspaper are described in Table 1. Some editions of the newspaper are missing or corrupted. So, we have used Google's search operator, "site:epaper.thedailystar.net" to retrieve those editions. We have collected 6203 numbers of articles. We have manually reviewed each article and identified COVID-19 related articles. We have found 1886 articles related with COVID-19. We have taken the help of COVID-19 keywords like "COVID-19", "COVID", "coronavirus", etc. for rigorous identification. The first local confirmed cases are reported on March 08. So, we have considered two phases of COVID-19 in Bangladesh: Phase-I (from January 1 to February 29) and Phase-II (from March 1 to April 30).

\section{B. Topic Modelling}

Topic Modelling, an unsupervised machine learning technique, is applied to a collection of documents (here articles) to generate the distribution of latent topics in the documents (Blei, 2003). The assumption of topic modelling algorithm, Latent Dirichlet Algorithm (LDA), is that each document i.e. article is a mixture of topics with probability distribution and each topic is a mixture of words with probability distribution. The inputs of LDA are: a collection of unlabeled articles and value of target number of topics to be extracted. The output of text-mining depends on preprocessing of text on the documents. Text pre-processing is comprised of three steps: Punctuation removal, Stop words removal and Lemmatization. Punctuations (like dot, comma, quote, etc.) do not contribute to text mining rather degrade the quality of output. We have used python library, $\boldsymbol{r} \boldsymbol{e}^{I}$ to remove punctuations from the articles. Stop words are common words (like this, that, so, etc.) appeared on text but do not carry discriminative information. To remove stop words from articles, we have applied python library, $\boldsymbol{n l t}^{2}$. Derived forms of dictionary words are often used on text because of tense, person, etc. Lemmatization helps to transform derived forms of words into their root form. We have applied WordNet corpus of nltk to conduct lemmatization. We have also appended the bi-grams with minimum count of 3 to the articles. With processed text, the articles are feed into a python library namely gensim $^{3}$ to conduct topic modelling. In the LDA algorithm, the number of topics $(\boldsymbol{k})$ is a hyper parameter. A smaller value of $\boldsymbol{k}$ will generate broad topics otherwise a larger value of $\boldsymbol{k}$ will generate specific topics. In both cases, it is difficult to interpret generated topics. Finding an optimal value of $\boldsymbol{k}$ is a difficult task. Topic coherence helps to find $\boldsymbol{k}$ number of semantically interpretable topics (Stevens, 2012). We have used gensim's coherence model to evaluate the topic coherence scores and find the optimal value of $\boldsymbol{k}$.

\section{Topic keywords and Themes Extraction}

To extract keywords of a specific topic, we have manually analyzed the articles of that topic with probabilities equal or greater than 0.90. For better human interpretation, we have mapped those topics into different themes. We have analyzed terms with higher probabilities of each topic to extract themes. Topic visualization graph by another python library,

\footnotetext{
${ }^{1}$ https://docs.python.org/3/library/re.html

${ }^{2}$ https://www.nltk.org/

${ }^{3} \mathrm{https}: / /$ radimrehurek.com/gensim/
} 
pyLDAvis (Sievert, 2014) is also used to identify topics representing similar theme.

\section{FINDINGS AND DISCUSSION}

On January 3-5, World Health Organization has confirmed about the viral pneumonia of unknown case at Wuhan in China (WHO, 2020, “Timeline of WHO's response to COVID-19").

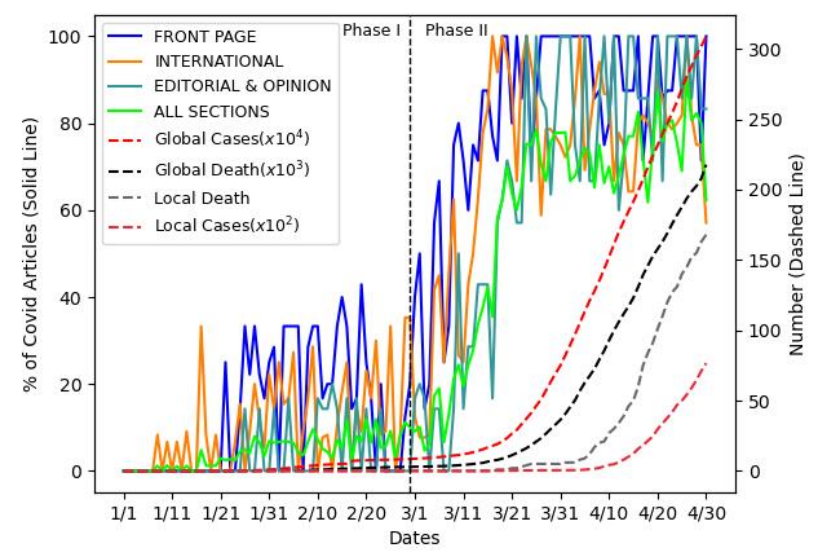

Fig 1. Rate of Presence of COVID-19 related articles in the newspaper (January 2020-April 2020)

On January 8 , the daily newspaper has published an article with headline, "US warns citizens in China over mystery virus" in 'INTERNATIONAL' section. This is the first article appeared in this newspaper about COVID-19. On January 9, China Authorities have confirmed the cause of new outbreak is due to 'novel coronavirus (2019-nCoV)'. On January 10, the newspaper has reported about novel coronavirus with headline, "New virus behind outbreak : Claim WHO, Beijing as 15 positive results detected". On January 12, the daily has published an article of first death in China from the outbreak. They have reported about the first case of new virus confirmed in Thailand on the next day. The reports about neighbor country, India's airport screening of China passengers have appeared on January 17-18. On January 21, WHO has published its first situation report on 'Novel Coronavirus (2019-nCoV)' (WHO, 2020, Jan 21). On January 22, the newspaper has published article on 'FRONT PAGE' with headline, "Virus alarm: Passenger screening begins at 2 airports". We have split the time of our study into two phases: Phase-I and Phase-II. Fig. 1 shows rate of presence of COVID-19 related articles and COVID-19 outbreak for both global and local scenarios. In Phase-I, there has been rise on cases and deaths globally but no local cases have yet confirmed. But in Phase-II, cases and deaths have been rising in both globally and locally. In Phase-I, the presence of COVID-19 related articles has been increasing on 'INTERNATIONAL' and 'FRONT PAGE' sections. In Phase-II, COVID-19 related articles are appearing on all over the sections due to increase in local cases and deaths. 'FRONT PAGE' has median presence rate of $87.5 \%$ in Phase-II while has median presence rate of $5 \%$ in Phase-I. 'INTERNATIONAL' section has median values of presence rate: $8.5 \%$ in Phase-I and $77 \%$ in Phase-II. There have been few articles both in 'EDITORIAL' and 'OPINION' sections about COVID-19 in Phase-I but in Phase-II the median value is increased to $71 \%$. The median of presence rate of COVID-
19 related articles in all sections has increased from $4.2 \%$ to $67.5 \%$. For better analysis we have split the extracted articles into different partitions based on time and types of section, see Table 2. For each partition mentioned in Table 2, we have applied topic modelling to extract topics from the newspaper articles.

Table 2. Partition Details

\begin{tabular}{|c|c|c|c|}
\hline ID & Partition Name & Sections & Phase \\
\hline A & Before Local Outbreak & All Section & I \\
\hline B & Outbreak on NEWS & $\begin{array}{c}\text { FRONT PAGE, BACK PAGE, } \\
\text { NEWS, CITY, COUNTRY }\end{array}$ & II \\
\hline C & $\begin{array}{c}\text { Outbreak On } \\
\text { EDITORIAL }\end{array}$ & $\begin{array}{c}\text { EDITORIAL, OPINION, } \\
\text { LETTERS TO THE EDITOR }\end{array}$ & II \\
\hline D & $\begin{array}{c}\text { Outbreak on } \\
\text { INTERNATIONAL }\end{array}$ & INTERNATIONAL & II \\
\hline
\end{tabular}

From the coherence model, we have determined the numbers of topics for each partition ('Before Local Outbreak'-11, 'Outbreak on NEWS'-15, 'Outbreak on EDITORIAL'-9 and 'Outbreak on INTERNATIONAL'- 16). We have then extracted topic's keywords and themes for each partition following Section II-C.

\section{A. Before Local Outbreak}

Table 3. Topic's keywords and their timeline of 'Before Local Outbreak'

\begin{tabular}{|c|c|c|c|}
\hline ID & Topic Keywords & Timeline & Freq. \\
\hline A0 & $\begin{array}{l}\text { force majeure, contract, clause, party, supply } \\
\text { chain, chinese, raw material, industry, } \\
\text { disruption }\end{array}$ & & 5 \\
\hline A1 & $\begin{array}{l}\text { virus, china, outbreak, wuhan, measure, } \\
\text { deadly, city, death, epidemic, travel, } \\
\text { lockdown }\end{array}$ & & 6 \\
\hline $\mathrm{A} 2$ & $\begin{array}{l}\text { china, case, new, chinese, virus, health, } \\
\text { outbreak, death, city, hubei, infected, } \\
\text { passenger, cruise ship, japan }\end{array}$ & & 28 \\
\hline A3 & $\begin{array}{l}\text { price, garlic, onion, market, ginger, trader, } \\
\text { sold, goods, misinformation, facebook }\end{array}$ & & 5 \\
\hline A4 & $\begin{array}{l}\text { airline, global risk, epidemic, impact, } \\
\text { economy, iata, championship }\end{array}$ & & 8 \\
\hline A5 & $\begin{array}{l}\text { bangladeshi, iedcr, passenger, airport, } \\
\text { infected, government, singapore, chinese, } \\
\text { student, dhaka, flight, port, hospital, patient, } \\
\text { quarantined, screening }\end{array}$ & & 30 \\
\hline A6 & $\begin{array}{l}\text { vaccine, scientist, new virus, effort, team, } \\
\text { infected, sars, develop, expert }\end{array}$ & & 11 \\
\hline A7 & $\begin{array}{l}\text { project, chinese, leave, chinese national, } \\
\text { padma bridge, construction, link, road, } \\
\text { national working, return }\end{array}$ & & 7 \\
\hline A8 & $\begin{array}{l}\text { china, virus, wuhan, new case, death, } \\
\text { outbreak, confirmed, reported, chinese, } \\
\text { spread, first, sars, infection }\end{array}$ & & 61 \\
\hline A9 & $\begin{array}{l}\text { virus, symptom, cold, protect infection, } \\
\text { contact, respiratory, spread, hand, fever, } \\
\text { cough, animal, human, pneumonia }\end{array}$ & & 11 \\
\hline A10 & $\begin{array}{l}\text { factory, import, money, bank, global, } \\
\text { service, order, economy }\end{array}$ & & 6 \\
\hline
\end{tabular}


The articles of this partition belong to all selected sections of the newspaper and are before the local confirmed cases. Table 3 shows keywords, presence in articles over time and frequency of each topic of this partition. After themes extraction, there are five themes: 'Global COVID-19 Outbreak' (Topic $A 1, A 2$ and A8), 'COVID-19 \& Bangladesh' (Topic $A 5$ ), 'Impact on Economy' (Topic $A O$, $A 4, A 7$ and $A 10)$, 'COVID-19 Research \& Development' (Topic $A 6$ and $A 9$ ) and 'Fake News \& Panic Buying' (Topic A3).

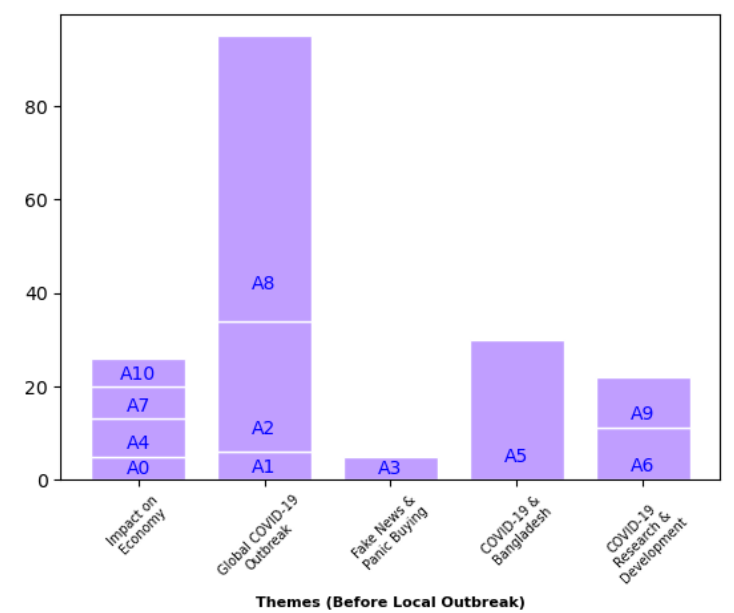

Fig 2. Themes and their topic distribution of 'Before Local Outbreak'

Fig. 2 shows the topic distribution among themes for this partition. 'Global COVID-19 Outbreak' is the most dominated theme in this partition with $53 \%$ articles. The articles belonging to this theme have reported about confirmed cases, deaths and preventive measures of COVID-19 in different cities, states, and countries (like Wuhan, China, United States, Japan, and Cruise Ship). 'COVID-19 Research \& Development' related articles of one topic have informed about the characteristics of the virus, symptoms of COVID-19, ways of transmission, etc. and articles of other topic have informed about treatments and vaccines of COVID-19. The articles of 'COVID-19 \& Bangladesh' have provided news about responses and preparedness of health authorities and government of Bangladesh. The synopsis of daily press briefing by Institute of Epidemiological, Disease Control and Research (IEDCR) is published regularly. Newspaper articles belonging to theme 'Impact on Economy' have mentioned about shortage of human resource resulting in closure of factory, shortage of raw material, ban on travel and postponement of events in China and around the world. 'Fake News \& Panic Buying' articles have showed the flow of misinformation about spread, treatment of COVID-19 in social media and panic buying from supermarkets driven by public fear.

\section{B. Outbreak on NEWS}

The articles of this partition are mostly about rural villages and cities of Bangladesh. There are few articles covering news about outside of Bangladesh too. Applying topic modelling, we have got 15 topics in this partition, detailed in Table 4. These topics are mapped into 9 themes, shown in Fig. 3. Topic $B 3$ is related to outside of Bangladesh. The theme, 'Local COVID-19 Outbreak' (Topic BI and B6) have reported about new cases, deaths, sample collations, testing reports, isolation, quarantines, lockdown etc. This theme is comprised of two topics: Topic B1 has covered the articles of COVID-19 related cases, deaths, measures and press briefing, and Topic B6 related articles have informed about death showing symptoms of rural people and response by rural authorities. 'Global COVID Outbreak' (Topic B3) has talked about daily spread of COVID-19, death toll and measures around all over the world specially China, Italy, United States and Europe countries.

Table 4. Topic's keywords and their timeline of 'Outbreak on NEWS'

\begin{tabular}{|c|c|c|c|}
\hline ID & Topic Keywords & Timeline & Freq. \\
\hline B0 & $\begin{array}{l}\text { school, colleges, online, ugc, } \\
\text { university, session, admission, } \\
\text { examination, teachers }\end{array}$ & & 36 \\
\hline B1 & $\begin{array}{l}\text { case, number, death, reported, } \\
\text { total, infected, infection, tested, } \\
\text { first, iedcr, positive, confirmed, } \\
\text { new case, transmission, spread }\end{array}$ & & 79 \\
\hline B2 & $\begin{array}{l}\text { price, hike, fall, panic buying, } \\
\text { loss, mask, vegetables, fruits, } \\
\text { flowers, farmers }\end{array}$ & & 36 \\
\hline B3 & $\begin{array}{l}\text { death, china, case, new, italy, } \\
\text { infection, hit, toll, europe, first, } \\
\text { outbreak, lockdown, global, } \\
\text { reported, united states, trump }\end{array}$ & & 144 \\
\hline B4 & $\begin{array}{l}\text { students, primary, secondary, } \\
\text { exam, classes, education, TV, air, } \\
\text { stay home }\end{array}$ & & 27 \\
\hline B5 & $\begin{array}{l}\text { bangladeshi, dhaka, flight, biman, } \\
\text { passenger, airport, airline, } \\
\text { suspended, stranded, route }\end{array}$ & & 52 \\
\hline B6 & $\begin{array}{l}\text { upazila, died, like symptom, fever, } \\
\text { cough, sample, suffering } \\
\text { isolation, district, village, test, } \\
\text { civil surgeon, sample collected }\end{array}$ & & 39 \\
\hline B7 & $\begin{array}{l}\text { migrant, garment, health, tea, } \\
\text { worker, factories, hospitals, safety, } \\
\text { pay, job, loss, work, workplace }\end{array}$ & & 126 \\
\hline B8 & $\begin{array}{l}\text { educational institution, shutdown, } \\
\text { students, worry, help, sanitizer, } \\
\text { food }\end{array}$ & & 21 \\
\hline B9 & $\begin{array}{l}\text { income, unpaid, family, hunger, } \\
\text { supply, demand, food, support, } \\
\text { aid, crowd, police }\end{array}$ & & 63 \\
\hline B10 & $\begin{array}{l}\text { home quarantine, returnee, fined, } \\
\text { violating, expatriate, uno, mask, } \\
\text { mobile court, coaching center, } \\
\text { magistrate }\end{array}$ & & 16 \\
\hline B11 & $\begin{array}{l}\text { government, sheikh hasina, prime } \\
\text { minister, press, health ministry, } \\
\text { secretary, } \\
\text { announcement, administration }\end{array}$ & & 106 \\
\hline B12 & $\begin{array}{l}\text { hospital, patient, doctor, nurse, } \\
\text { ppe, infected, facility, icu, bed, } \\
\text { treatment, equipment, medical } \\
\text { college, quarantine, healthcare, } \\
\text { positive, private }\end{array}$ & & 136 \\
\hline B13 & $\begin{array}{l}\text { test kit, sample, iedcr, lab, dghs, } \\
\text { tested, expert, research, } \\
\text { gonoshasthaya kendra }\end{array}$ & & 30 \\
\hline B14 & $\begin{array}{l}\text { rice, relief, food, farmers, poor, } \\
\text { family, district, upazila, union, } \\
\text { boro, police }\end{array}$ & 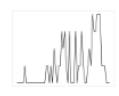 & 59 \\
\hline
\end{tabular}

The necessity and availability of medical supplies (like PPE, face-mask, oxygen, ICU, hospital), human resource (like nurse, doctor), testing facilities (like test kit, sample collection) around the country have been informed in theme, 'Operation Support \& Logistics' (Topic B12 and B13). The responses, law-enforcement and financial supports of 
government and local administration (like upazila, district) have been reported in 'Authority Response' (Topic B10 and B11). The information about travel restrictions and measures been reported on 'Travel Monitoring' (Topic B5). 'Impact on Education' has three topics (Topic BO, B4 and B8) reporting students related news. Topic $B O$ related news articles have talked about policies of educational institutes about preparation for COVID-19, closure, admission, examination and class.

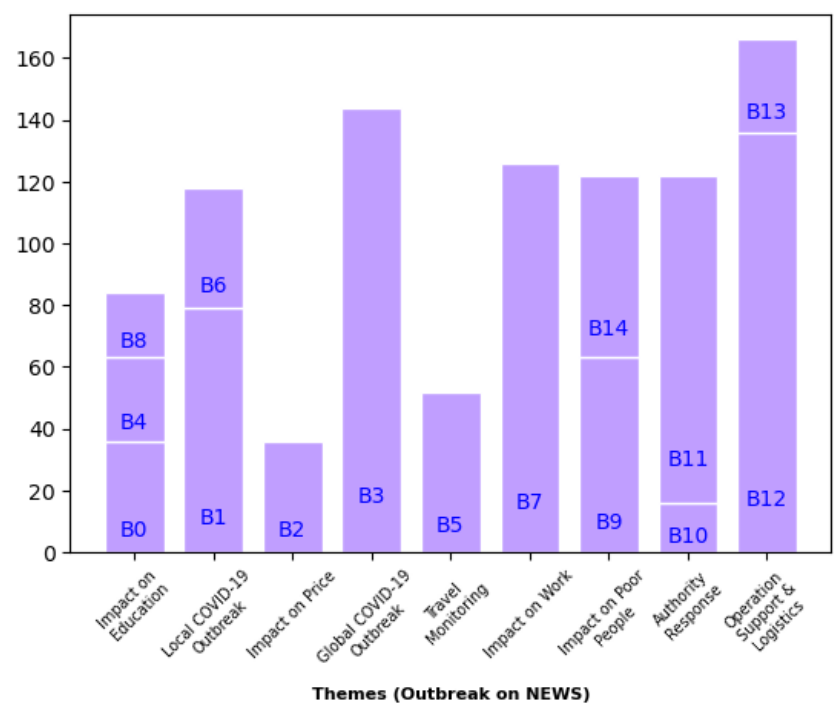

Fig. 3. Themes and their topic distribution of 'Outbreak on NEWS'

Topic $B 4$ has been centered on virtual classes through TV of primary and secondary education and its effectiveness. Topic $B 8$ articles have showed students voluntary activities by making hand sanitizer on labs and helping poor people by distributing food. 'Impact on Work' (Topic B7) articles have focused on COVID-19 risk, workplace safety, job loss, low wage, non-payment and necessity of stimulus package of workers especially migrant, garment, health and tea. 'Impact on Price' (Topic B2) has covered news related with price instability (hike or fall) of daily essentials i.e. vegetables, fruits, mask, etc., all over the country. So, panic buying and farmers' loss have also been reported. 'Impact on Poor People' has two topics: Topic B9 and B14. Topic B9 has covered news articles reporting about hunger due to noincome in shutdown, demand of food in streets of poor peoples. Topic B14 has reported about government's distribution of rice and daily essentials to support poor people all over the country. The top themes in this partition in terms of reported articles are: 'Operation Support \& Logistics' (17\%), 'Global COVID19 Outbreak' (15\%), 'Local COVID-19 Outbreak' (12\%). 'Impact on Work', 'Authority Response' and 'Impact on Poor People' have about same percentage of articles (13\%).

\section{Outbreak on EDITORIAL}

In this partition, the articles cover discussions and opinions from editorial boards, other expert authors and readers. There are 9 topics (detailed in Table 5) and 6 themes (shown in Fig. 4 ) in this partition. All but Topic $C 8$ are related to Bangladesh. 'Impact on Economy' has two topics: Topic $C 3$ and $C 7$. Topic $C 3$ has discussion about struggle of people in especially day laborer due to 'stay home' policy and price hike of essential goods. In Topic C7, the authors have discussed about impact on stock market, ready-made-garment (RMG) industry, price of daily essential goods and panic buying. They have also analyzed government support packages to recover from this crisis. There are about $37 \%$ articles related to 'Impact on Economy' in this partition. 'COVID-19 Protective/Preventive Measure', the second most dominated articles (about 28\%), is comprised of three topics-Topic Cl, $C 2$ and C6. Topic $C 1$ has reported about discussion of the preparedness of authorities and possible risk due to COVID19.

Table 5. Topic's keywords and their timeline of 'Outbreak on EDITORIAL'

\begin{tabular}{|c|c|c|c|}
\hline ID & Topic Keywords & Timeline & Freq. \\
\hline $\mathrm{C} 0$ & $\begin{array}{l}\text { information, social } \\
\text { domestic abuse, human } \\
\text { abuse, child }\end{array}$ & & 19 \\
\hline $\mathrm{C} 1$ & $\begin{array}{l}\text { ready, manage, mismanage, } \\
\text { measure, ensure, faith, testing, } \\
\text { isolation }\end{array}$ & & 13 \\
\hline $\mathrm{C} 2$ & $\begin{array}{l}\text { precaution, prevention, impose, } \\
\text { strict measure, social distance, } \\
\text { close }\end{array}$ & & 10 \\
\hline C3 & $\begin{array}{l}\text { stay home, work, tea, worker, } \\
\text { price hike, risk }\end{array}$ & & 18 \\
\hline $\mathrm{C} 4$ & $\begin{array}{l}\text { education, continue, gap, session, } \\
\text { teaching, tertiary, learning, student }\end{array}$ & & 19 \\
\hline C5 & $\begin{array}{l}\text { health worker, doctors, ppe, test } \\
\text { kit, icu, bed, ventilator, patient, } \\
\text { test, hospitals, medical, treatment }\end{array}$ & & 20 \\
\hline C6 & $\begin{array}{l}\text { preparedness, test, emergency, } \\
\text { public awareness, priority, } \\
\text { implement, lesion, mechanism, } \\
\text { sample collection, research }\end{array}$ & & 43 \\
\hline C7 & $\begin{array}{l}\text { recession, stock market, rmg } \\
\text { industry, economy, panic buying, } \\
\text { price, farmer }\end{array}$ & & 70 \\
\hline $\mathrm{C} 8$ & $\begin{array}{l}\text { humanity, refugee crisis, high risk, } \\
\text { who, trump, global, pandemic }\end{array}$ & & 24 \\
\hline
\end{tabular}

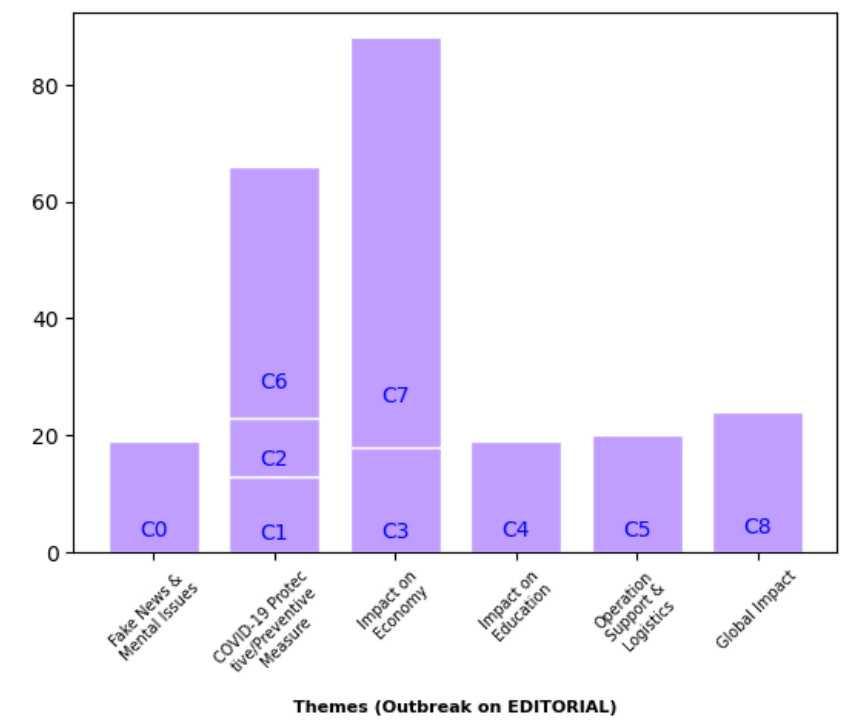

Fig 4. Themes and their topic distribution of 'Outbreak on EDITORIAL' 
The authors have also discussed about the effectiveness of safety measures, large-scale testing, home isolation, etc. Topic $C 2$ has discussion about basic precautionary steps like prevention, closure of schools, strict measures, social distancing, etc. The authors have also discussed about nations' research on test kits and $S A R S-C o V-2$ genome sequencing. Topic C6 has opinions about necessity of public awareness, emergency preparedness, widespread testing, and suspected case detection mechanism, samples collection and learning from both other nations and previous pandemics. In 'Impact on Education' (Topic C4), the authors have expressed worries about long gap in educations ranging from primary to tertiary level and proposed ways to continue education in this crisis with change in teaching modality. In 'Operation Support \& Logistics' (Topic C5), the authors have expressed opinions about the situation of health care sectors: doctors, nurses, masks, personal protective equipment, testing facility, kits, ventilators, medical waste management, treatment of nonCOVID-19 patient etc. They have also suggested to announce incentives for front-line workers. 'Global Impact' (Topic C8) has talked about the global crisis due to COVID-19. The authors have emphasized to take immediate actions on densely populated refugee camps e.g. Rohingya on Bangladesh and rural areas. They have constructively criticized world leaders' response to COVID-19. 'Fake News \& Mental Issues' having Topic $C O$ has discussions on risk from abundant flow of misinformation, domestic women violence and child abuse during the pandemic.

\section{Outbreak on INTERNATIONAL}

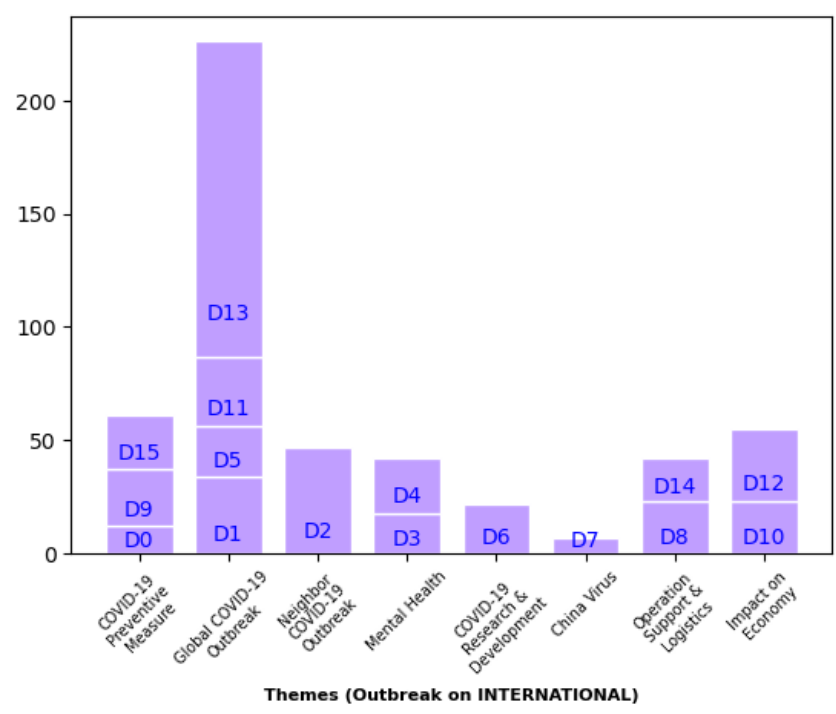

Fig. 5. Themes and their topic distribution of 'Outbreak on INTERNATIONAL'

The articles of this partition cover news about other countries of the world. We have extracted 16 topics (detailed in Table 6) and 8 themes (shown in Fig. 5) in this partition. 'Global COVID-19 Outbreak' theme consists of four topics. Topic D1 and D5 related articles have reported about the new confirmed cases, newly infected countries, spread of coronavirus and measures e.g. lockdown imposed by authorities of different regions. Topic D11 and D13 related articles have reported about death and fatality rate of COVID19 in different countries. In this partition, $45 \%$ articles belong to 'Global COVID-19 Outbreak'. 'COVID-19 Preventive Measure' theme related articles (12\%) have discussed about different preventive measures imposed by different authorities. Topic DO dominated articles have talked about travel bans, canceling events, limiting tourist spots (like Everest) and restricting public gatherings in praying places. Topic D9 related articles have reported about importance of wearing mask to protect from COVID-19, relative usefulness of different kinds of mask (e.g. surgical mask, coating mask, etc.) and inspiring people to obey 'stay home' policy. Topic D15 newspaper articles have published expert's advice towards people and authorities: to make face mask as mandatory, to response quickly, to conduct press briefing about situations, to disinfect surroundings, etc.

Table 6- Topic's keywords and their timeline of 'Outbreak on INTERNATIONAL

\begin{tabular}{|c|c|c|c|}
\hline ID & Topic Keywords & Timeline & Freq. \\
\hline D0 & $\begin{array}{l}\text { restriction, everest, mosque, } \\
\text { measure, fear, lockdown, stopped, } \\
\text { limited, public gathering, warning }\end{array}$ & & 12 \\
\hline D1 & $\begin{array}{l}\text { virus, case, death, positive, patient, } \\
\text { test, infection, tested, disease, } \\
\text { infected }\end{array}$ & & 34 \\
\hline D2 & $\begin{array}{l}\text { india, prime minister, delhi, } \\
\text { narendra modi, mumbai }\end{array}$ & & 47 \\
\hline D3 & $\begin{array}{l}\text { lockdown, violence, } \\
\text { confinement, } \begin{array}{l}\text { quarantine, } \\
\text { home, life, } \\
\text { holice, }\end{array} \\
\text { domestic_violence }\end{array}$ & & 18 \\
\hline D4 & $\begin{array}{l}\text { lockdown, measure, medium, } \\
\text { press, health organization, } \\
\text { freedom, urged }\end{array}$ & & 24 \\
\hline D5 & $\begin{array}{l}\text { first case, positive, tested, spread, } \\
\text { patient, reported, confinement, } \\
\text { outbreak }\end{array}$ & & 22 \\
\hline D6 & $\begin{array}{l}\text { drug, trial, blood, } \begin{array}{l}\text { disease, } \\
\text { treatment, research, } \\
\text { antibody, } \\
\text { hydroxychloroquine, } \\
\text { malaria, scientist }\end{array}\end{array}$ & & 22 \\
\hline D7 & $\begin{array}{l}\text { china virus, origin, conspiracy } \\
\text { theory, wuhan virus }\end{array}$ & & 7 \\
\hline D8 & $\begin{array}{l}\text { oxygen, crisis, war, air, hospital, } \\
\text { health system }\end{array}$ & & 23 \\
\hline D9 & $\begin{array}{l}\text { mask, lockdown, coating, help, } \\
\text { essential, emergency, stay home }\end{array}$ & & 25 \\
\hline D10 & $\begin{array}{l}\text { worker, factory, european, job, } \\
\text { economy, help, crisis }\end{array}$ & & 23 \\
\hline D11 & $\begin{array}{l}\text { death, case, toll, death toll, } \\
\text { lockdown, tally, declared, fatality }\end{array}$ & & 31 \\
\hline D12 & $\begin{array}{l}\text { economic, economy, bank, } \\
\text { tourism, business, worst, recession }\end{array}$ & & 32 \\
\hline D13 & $\begin{array}{l}\text { death, number, reported, first, toll, } \\
\text { outbreak, new case, total, } \\
\text { confirmed, death toll, died }\end{array}$ & WN/W/NPM & 139 \\
\hline D14 & $\begin{array}{l}\text { test, mask, ventilator, production, } \\
\text { test kit, medical doctor }\end{array}$ & uniwn 1 u & 19 \\
\hline
\end{tabular}


D15 face mask, disinfectant, press briefing, fund, response

'Operation Support \& Logistics' has two topics: Topic $D 8$ and $D 14$ related newspaper articles have discussed about crisis of mask, ppe and oxygen support, test kits unavailability, overflow of hospital, struggles of health workers, necessity of ventilator, etc. Topics $D 10$ and $D 12$ belonging to theme 'Impact on Economy' have focused on the economic crisis. Topic D10 related articles have talked about job loss in Europe among workers and stories of aid by different organizations. The characteristics of COVID-19: symptoms, treatments i.e. use of plasma therapy, efficiency of malaria drug i.e. hydroxychloroquine and progress of vaccines by scientists have been reported in Topic D6 mapped to 'COVID-19 Research \& Development'. Topic D12 related articles have contained prediction of world-wide recession and plans of recovery. Topic D2 related articles have informed about COVID-19 situation of India, neighbor country of Bangladesh. Geographically, Bangladesh is surrounded by India from almost all sides. 'Neighbor's COVID-19 Outbreak' theme has reported about confirmed cases, death numbers, test and treatment strategies, and preventive measures of that country. The mental issues of people during pandemic have been discussed on theme 'Mental Health' having Topic D3 and D4. Topic D3 has reported about increase of violence on women and child due to lockdown measure. Topic D4 has covered health organizations' reporting about the importance of freedom of people and urging government to ensure the mental happiness during the pandemic. 'China Virus' having Topic D7 has reported about conspiracy theories of allegation on China for the coronavirus outbreak.

\section{CONCLUSION}

The content analysis of newspaper articles using topicmodelling approach has revealed that COVID-19 has dominated significantly since first cases confirmed in Bangladesh. The most common themes of reporting have been spread of COVID-19, operation support \& logistics related to COVID-19 and impact on economy. The local news related articles have focused on spread of COVID-19 in rural areas, responses of local authorities, monitoring of government, impact on job security \& workplace safety and hardships of people due to countrywide shut down. The experts have repetitively talked about the enforcement and effectiveness of different COVID-19 preventive/protective measures in editorial and opinion columns. We have also found that newspaper articles have reported about situation of COVID19, preventive measures, situation of healthcare system, its impact on people, etc. and different countries including neighbor country of Bangladesh i.e. India. In future studies, other popular news media in Bangladesh (like Television, Facebook, etc.) can be accumulated with newspaper. The time period of study can be extended as the pandemic is going on after April 2020.

\section{ACKNOWLEDGEMENT}

We want to express our gratitude to all the health workers of Bangladesh fighting COVID-19.

\section{REFERENCES}

1 World Health Organization (2020, January 21). Novel coronavirus (2019-ncov): Situation report 1.

2 World Health Organization (2020, October 10). Timeline of who's response to covid-19. Retrieved from

https://www.who.int/emergencies/diseases/novelcoronavirus-2019/

3 World Health Organization (2020, March 09). Coronavirus disease 2019 (covid-19): Situation report 49.

4 Institute of Epidemiology, Disease Control and Research (2020, October 10). COVID-19 Information of Bangladesh. Retrieved from https://corona.gov.bd/press-release

5 Akanda, A. M. E. A., \& Haque, M. A. (2013). Newspaper reading habits of university graduate students in Bangladesh: A case study. International Journal of Research in Applied, Natural and Social Sciences (IMPACT: IJRANSS), 1(3), 1-8.

6 Genilo, J. W., Asiuzzaman, M., \& Osmani, M. M. H. (2016). Small circulation, big impact: English language newspaper readability in Bangladesh. Advances in Journalism and Communication, 4(4), 127-148.

7 Liu, Q., Zheng, Z., Zheng, J., Chen, Q., Liu, G., Chen, S., ... \& Zhang, C. J. (2020). Health Communication Through News Media During the Early Stage of the COVID-19 Outbreak in China: Digital Topic Modeling Approach. Journal of Medical Internet Research, 22(4), e19118.

8 Mahima, B. N., Tiwari, H. K., Mahapatra, P., Amudhan, S., \& Rao, G. N. (2020). COVID-19 epidemiology: Through the eyes of vernacular newspapers. Indian Journal of Public Health, 64(6), 217.

9 Islam, M. D., \& Siddika, A. (2020). COVID-19 and Bangladesh: A study of the public perception on the measures taken by the government. EdArXiv.

10 Bhuiyan, A. I., Sakib, N., Pakpour, A. H., Griffiths, M. D., \& Mamun, M. A. (2020). COVID-19-related suicides in Bangladesh due to lockdown and economic factors: case study evidence from media reports. International Journal of Mental Health and Addiction.

11 Abd-Alrazaq, A., Alhuwail, D., Househ, M., Hamdi, M., \& Shah, Z. (2020). Top concerns of tweeters during the COVID-19 pandemic: infoveillance study. Journal of medical Internet research, 22(4), e19016.

12 Zhao, Y., \& Xu, H. (2020). Chinese public attention to COVID-19 epidemic: Based on social media. medRxiv.

13 Hilton, S., \& Hunt, K. (2011). UK newspapers' representations of the 2009-10 outbreak of swine flu: one health scare not over-hyped by the media? $J$ Epidemiol Community Health, 65(10), 941-946.

14 Choi, D. H., Yoo, W., Noh, G. Y., \& Park, K. (2017). The impact of social media on risk perceptions during the MERS outbreak in South Korea. Computers in Human Behavior, 72, 422-431.

15 Kim, E. H. J., Jeong, Y. K., Kim, Y., Kang, K. Y., \& Song, M. (2016). Topic-based content and sentiment 
analysis of Ebola virus on Twitter and in the news. Journal of Information Science, 42(6), 763-781.

16 Miah, M. D., Kabir, M. H., Koike, M., \& Akther, S. (2011). Major climate-change issues covered by the daily newspapers of Bangladesh. The Environmentalist, 31(1), 67-73.

17 The Daily Star. (2020, October 10). Retrieved from The Daily Star | Bangladesh: https://epaper.thedailystar.net/

18 Blei, D. M., Ng, A. Y., \& Jordan, M. I. (2003, Jan). Latent dirichlet allocation. Journal of machine Learning research, 3, 993-1022.

19 Stevens, K., Kegelmeyer, P., Andrzejewski, D., \& Buttler, D. (2012, July). Exploring topic coherence over many models and many topics. Proceedings of the 2012 Joint Conference on Empirical Methods in Natural Language Processing and Computational Natural Language Learning, (pp. 952-961).

20 Sievert, C., \& Shirley, K. (2014, June). LDAvis: A method for visualizing and interpreting topics, (pp. 63-70). 